\title{
Using citizen-science data to identify local hotspots of seabird occurrence
}

Eric J. Ward, Kristin N Marshall, Toby Ross, Adam Sedgley, Todd Hass, Scott F. Pearson, Gerald Joyce, Nathalie J. Hamel, Peter J. Hodum, Robert C. Faucett

Seabirds have been identified and used as indicators of ecosystem processes such as climate change and human activity in nearshore ecosystems around the globe. Temporal and spatial trends have been documented at large spatial scales, but few studies have examined more localized patterns of spatiotemporal variation, by species or functional group. In this paper, we apply spatial occupancy models to assess the spatial patchiness and interannual trends of 18 seabird species in the Puget Sound region (Washington State, USA). Our dataset, the Puget Sound Seabird Survey of the Seattle Audubon Society, is unique in that it represents a seven-year study, collected with a focus on winter months (October - April). Despite historic declines of seabirds in the region over the last 50 years, results from our study are optimistic, suggesting increases in probabilities of occurrence for 14 of the 18 species included. We found support for declines in occurrence for whitewinged scoters, brants, and 2 species of grebes. The decline of Western grebes in particular is troubling, but in agreement with other recent studies that have shown support for a range shift south in recent years, to the southern end of California Current. 


\section{Using citizen-science data to identify local hotspots of species occurrence}

2 Eric J. Ward ${ }^{1, *}$

3 Kristin N. Marshall

4 Toby $\operatorname{Ross}^{2,3}$

5 Adam Sedgley ${ }^{2,3}$

6 Todd Hass , $^{4}$

7 Scott F. Pearson 6

8 Gerald Joyce S $^{3,7}$

9 Nathalie J. Hamel ${ }^{3,8}$

10 Peter J. Hodum $^{3,9}$

11 Rob Faucett ${ }^{3,5}$

$12{ }^{\mathrm{I} C o n s e r v a t i o n ~ B i o l o g y}$ Division, Northwest Fisheries Science Center, National Marine Fisheries

13 Service, National Oceanic and Atmospheric Administration, Seattle WA 98112

$14{ }^{2}$ Seattle Audubon Society, Seattle, WA, 98115

$15 \quad{ }^{3}$ Science Committee, Seattle Audubon Society, Seattle, WA, 98115

$16{ }^{4}$ School of Marine and Environmental Affairs, Seattle, WA, 98105

$17{ }^{5}$ Burke Museum of Natural History and Culture, University of Washington, Seattle, WA, 98195

$18{ }^{6}$ Wildlife Science Division, Washington Department of Fish and Wildlife, Olympia, WA, 98501

$19{ }^{7}$ Moon Joyce Resources, Seattle, WA, 98125

$20{ }^{8}$ Puget Sound Partnership, Tacoma, WA, 98421

21 'Biology Department, University of Puget Sound, Tacoma, WA, 98416

$22 *$ eric.ward@noaa.gov

23 Author to whom correspondence should be sent: Eric J. Ward; Conservation Biology Division,

24 Northwest Fisheries Science Center, National Marine Fisheries Service, National Oceanic and

25 Atmospheric Administration, Seattle, Washington 98112 USA; ric.ward@noaa.gov 
Introduction

27 Ecologists and conservation practitioners have long focused on describing species

28 distribution and estimating changes in abundance (Holmes 2001) or occurrence through time

29 (MacKenzie et al. 2006). Using species distribution modeling to identify the spatial variability

30 and hotspots of a species' distribution has multiple implications for science and management.

31 From a conservation perspective, incorporating spatial variation in models may assist in selecting

32 areas to protect or predicting where species are likely to persist (Cabeza \& Moilanen 2001;

33 Naujokaitis-Lewis et al. 2009). From a theoretical ecology perspective, null or neutral models of

34 species' occurrence may be useful in predicting species diversity or community assembly (Gotelli

35 2000; Gotelli \& McGill 2006). Finally, the inclusion of spatial variation has implications for

36 management and policy in that accounting for spatial heterogeneity may help in forecasting how

37 species may respond to future environmental conditions, such as range shifts in response to

38 climate change (Jetz et al. 2007).

39

In addition to quantifying spatial variation, species distribution modeling can be used to

40 assess temporal trends in occurrence, which themselves may be spatially structured as well.

41 Mechanisms responsible for spatially structured trends may include changing habitat conditions,

42 behavior, or prey availability (Ward et al. 2010). Spatially structured anthropogenic disturbances

43 (e.g. wildfires, oil spills, climate change, urbanization) may have similar impacts, and

44 collectively ignoring such underlying spatial variation when it exists may lead to poor estimation

45 of temporal trends (Hoeting et al. 2008).

46 Models that incorporate both spatial and temporal variation represent a rapidly evolving

47 field in ecology (Hooten \& Wikle 2008; Latimer et al. 2006; Shelton et al. 2014). While many of

48 these methods have been in the statistical literature for decades (Banerjee et al. 2005; Cressie \&

49 Wikle 2011), ecological data often present a unique set of challenges relative to data from other

50 fields. Compared to other disciplines, ecological data on species abundance is often corrupted by 


\section{PeerJ Reviewing Manuscript}

51 observation error, which represents uncertainty arising from taking measurements or sampling a

52 fraction of the population (Holmes 2001). Similarly, in conducting studies of species presence-

53 absence, detections may be missed, resulting in false-negatives (MacKenzie et al. 2006). Because

54 of recent computational advances, statistical models that include both spatial and temporal

55 variation are now widely available to ecologists and offer a powerful tool for assessing changes

56 in species distributions through time.

57 As data hungry methods have advanced, monitoring programs have suffered in recent

58 years because of declining budgets and an increased need for cost efficient survey techniques. In

59 the face of recent reductions in monitoring programs, one potentially underutilized resource is

60 citizen science, which may be a useful tool for conducting baseline environmental monitoring or

61 helping to inform management actions or restoration activities (Cooper et al. 2007). Participation

62 in these volunteer-based programs appears to have increased in recent years (Silvertown 2009).

63 Some of the longest running citizen-science programs in North America are related to bird

64 watching. Large-scale volunteer programs like the Audubon Christmas Bird Count and the North

65 American Breeding Bird Survey (BBS) have been effective at collecting vast amounts of survey

66 data on commonly occurring bird species (Sauer et al. 2014). The strength of these programs is

67 their duration, large spatial extent, and consistent methodologies over time, enabling them to be

68 useful in monitoring species assemblages and distribution shifts in response to changing climate

69 (Hitch \& Leberg 2007).

70 In the Pacific Northwest, similar regional-scale citizen-science programs focused on

71 seabirds have been established. These include the Coastal Observation and Seabird Survey

72 Team (COASST; Hamel et al. 2009; Litle et al. 2007; Parrish et al. 2007) and the British

73 Columbia Coastal Waterbird Survey (Crewe et al. 2012), which have also been developed to

74 address conservation questions and establish baseline monitoring. These regional citizen-science

75 programs help inform restoration actions in Puget Sound (Washington State), where one of the 
76 largest ecosystem restoration programs in the nation is underway (Puget Sound Partnership

77 2014). The Puget Sound ecosystem is part of the Salish Sea (which also includes the Strait of

78 Juan de Fuca and the Strait of Georgia), and has been affected by widespread environmental

79 degradation largely associated with increased urbanization (effects summarized in Puget Sound

80 Partnership 2009; Ruckelshaus \& McClure 2007). Puget Sound consists of over 4,000 km of

81 coastline, with a suite of high-value ecosystem services, including commercial fisheries and

82 various recreation opportunities (e.g. Tallis \& Polasky 2009). A portfolio of ecosystem indicators

83 has been developed and incorporated into restoration goals for the Puget Sound region to monitor

84 ecological conditions, including seabirds (Kershner et al. 2011; Puget Sound Partnership 2013).

85 A limitation of using the data from many citizen-science programs-including those from

86 regional seabird monitoring programs in the Pacific Northwest-has been that survey effort is

87 generally not quantified. A limited number of agency-funded seabird surveys have been

88 conducted that allow the assessment of trends. To assess winter seabird densities, the Washington

89 Department of Fish and Wildlife (WDFW) has conducted annual aerial surveys since 1992,

90 representing a 6-week snapshot of density (Anderson et al. 2009; Nysewander et al. 2005).

91 These annual transects occur in $13-18 \%$ of the nearshore ( $<20 \mathrm{~m}$ depth) and $3-6 \%$ of the offshore

92 ( $>20 \mathrm{~m}$ depth) marine waters in Puget Sound, ranging from southern Puget Sound to the Canadian

93 border. Results from the WDFW aerial seabird surveys suggested that the density of some

94 species, including Western Grebes (Aechmophorus occidentalis), has declined over the last two

95 decades (Bower 2009; Evenson 2010; Vilchis et al. 2014). However, the cause(s) of these

96 declines and the effects of environmental drivers on seabird density remain largely unknown. To

97 complement the WDFW seabird survey both spatially and temporally, and to establish further

98 baseline monitoring of local seabird species occurrence and abundance in winter months, the

99 Seattle Audubon Society initiated the shore-based Puget Sound Seabird Survey (PSSS) in 2007.

100 This program is unique in Puget Sound, in that volunteers monitor study sites in nearshore 
101 habitats monthly, from late fall to early spring (October-April). The October-April period was

102 chosen because this is the window of greatest seabird abundance and diversity for this ecosystem.

103 This survey also represents a good example of a scientifically rigorous citizen-science effort

104 because survey effort is quantified and volunteers are trained annually and are the subject of

105 ongoing validation studies to quantify biases, such as species misidentification.

106 Recent research has demonstrated that rigorous statistical models can be applied to

107 volunteer-based surveys, yielding a relatively large impact, particularly when agency or industry-

108 led data collection efforts are limited (Thorson et al. 2014a). The primary objective of our

109 analysis was to apply spatiotemporal models to data from the Puget Sound Seabird Survey to (1)

110 evaluate relative hotspots of occurrence over the period 2007-2014, (2) evaluate temporal trends

111 in occupancy over this period, and (3) establish a baseline for future monitoring in the region.

112 These spatial and temporal estimates of occupancy may also be useful to refine the list of

113 indicator species used to quantify ecosystem change or restoration progress.

\section{Methods}

\section{PSS Survey Data Collection}

116 Beginning in October 2007, teams of 2-4 volunteer birdwatchers were trained by Seattle

117 Audubon staff to collect data on birds in the nearshore environment of Puget Sound. Though the

118 species encountered includes waterfowl, we collectively refer to all species as 'seabirds'. Each

119 observer team was responsible for monthly surveys (October - April) at selected sites. Many of

120 the seabird species in the region overwinter in Puget Sound, and are of highest abundance from

121 late fall - early spring. The PSSS survey sites were selected non-randomly due to dependence on

122 public access (parks, beach access), but they were selected to be spaced at least $1.6 \mathrm{~km}$ apart.

123 Observer teams recorded all species present out to $300 \mathrm{~m}$ from shore for a minimum of 15

124 minutes, but some site visits lasted up to 60 minutes. To minimize the variability of weather 
125 conditions, tidal stage, and the risk of double counting birds at multiple survey sites, volunteer

126 teams completed their monthly surveys on the same date within a specific four-hour window (two

127 hours on either side of daylight high tide) on the first Saturday of each month. In each subsequent

128 year of surveys, we added sites to cover parts of northern and southern Puget Sound. For this

129 study, we limited our analysis to 62 sites with at least 15 visits (Fig. 1; Table 1). Additional

130 details on the survey and monitoring, as well as additional maps can be found on the PSSS

131 website, www.seabirdsurvey.org.

\section{Species Selection}

133 Over the first seven years of the PSSS (the most recent ending in spring 2014), observer

134 teams recorded 75 unique seabird species. While many of these species may be useful as

135 indicators of various ecosystem processes or human impacts, we focused our analysis on 18

136 species that have previously been identified as useful seabird indicator species in the region

137 (Table 2; Pearson \& Hamel 2013) because of their relative abundance and dependence on the

138 marine waters of the Puget Sound (Gaydos and Pearson 2011). These species can be aggregated

139 into five distinct groups: alcids, cormorants, grebes, loons, and waterfowl. Some of the species

140 breed locally in Puget Sound, while others are transient in the Sound, breeding elsewhere (Table

141 2). Similarly, the species represent a range of diets and behaviors (Pearson \& Hamel 2013), from

142 piscivores (alcids, loons, grebes, cormorants) to omnivores (seaducks and other waterfowl).

\section{Statistical Modeling}

144 For each species, we constructed matrices of presence-absence, dimensioned by the

145 number of unique month-year combinations $(t=49)$ and sites $(n=62)$. Sites that were not visited

146 during a given month were treated as NA values. We constructed a spatial occupancy model

147 separately for each species, to incorporate spatial patchiness, as well as annual and seasonal

148 variation. The model describing the probability of species presence can be represented as 
$149 z_{i, j} \operatorname{Ber}\left(\phi_{i, j}\right)$, where $z_{i, j} \quad$ represents the unobserved presence-absence $(1,0)$, and

$150 \operatorname{logit}\left(\phi_{i}\right)=B X_{i}+E T_{i}+\varepsilon$, where $\phi_{i}$ represents the site-specific occupancy probabilities at

151 time $i, X_{i}$ represents a matrix of covariates (Intercept, Month, Month ${ }^{2}$, Year, Year $\left.{ }^{2}\right), B$ represents a

152 vector of estimated coefficients (shared across sites and time periods), $E$ represents a linear offset

153 coefficient for sampling effort $\left(T_{i}\right)$, and $\varepsilon$ represents a vector of spatially correlated random

154 effects. We included time spent ( $T_{i}$ in minutes, ranging from $\left.15-60\right)$ as a measure of effort to

155 account for the higher chance of recording a species present during longer visits. The spatially

156 correlated random effects are assumed to have the distribution $\varepsilon \operatorname{MVN}(0, \Sigma)$. For simplicity,

157 we modeled the covariance matrix $\Sigma$ as an exponential covariance function,

$158 \Sigma_{i, j}=\sigma^{2} \cdot I_{i, j}+\tau \cdot \exp \left(-d_{i, j} / \gamma\right)$, where I represents an identity matrix, $d_{i, j}$ is the Euclidian

159 distance between sites $i$ and $j$, and the scaling parameters ( $\tau, Y$ ) control how quickly

160 covariance decays as a function of distance (Banerjee et al. 2005; Ward et al. 2012). Our model

161 could be modified to include more complex covariance functions (Cressie \& Wikle 2011) or

162 spatial random effects that also vary temporally (Shelton et al. 2014). Because our model also

163 includes an observation error component, however, we chose to make these spatial deviations

164 temporally constant. The observation model, linking latent unobserved states ( $\left.z_{i, j}\right)$ to data (

$\left.165 y_{i, j}\right)$ can be written as $y_{i, j} \vee z_{i, j} \operatorname{Ber}\left(p \cdot z_{i, j}\right) \quad$ (Royle \& Kery 2007), where $p$ represents the

166 probability of detection when a species is present.

167 All Markov Chain Monte Carlo (MCMC) estimation was conducted in R and JAGS

168 (Plummer 2003; R Core Team 2014), using the R2jags package (Su \& Yajima 2014). We ran five

169 parallel MCMC chains for each species, with a burn-in of 100,000 draws and additional sampling

170 of 50,000 MCMC draws. Trace plots were used to visually assess convergence, and the Gelman-

171 Rubin statistic (Gelman \& Rubin 1992) was used to quantify successful convergence. Not

172 surprisingly, the only parameters that did not successfully converge (potential scale reduction 
173 factor $>1.05)$ were several latent states $(z)$ at sites that were not visited by observers in certain

174 months. For the purposes of visualizing predicted hotspots of occupancy in Puget Sound, we used

175 our model output to generate predictions (spatial maps, temporal trends) of species occupancy for

176 a standardized 15-minute survey. In addition to making these predictions for each of the 18

177 species included in our analysis, we attempted to identify hotspot areas, or the sites whose

178 estimated occupancy probability was above the upper quartile (75\%) across all sites. Finally, we

179 generated specific occupancy probabilities for the five seabird groups: alcids, cormorants, loons,

180 grebes, and waterfowl. For each group, the probability of occupancy for a group (corresponding

181 to any species from that group being present) was calculated as $1-\prod_{i=1}^{s p}\left(1-\phi_{i}\right)$.

\section{Results}

183 Our species occupancy maps reveal localized hotspots of occurrence in Puget Sound for

184 some alcid and cormorant species (rhinoceros auklet, pelagic cormorant, Brandt's cormorant (Fig.

185 2) as well as for loons and some waterfowl species like harlequin ducks (Fig. 3). The individual

186 species maps show that some species are ubiquitous in all nearshore habitat (horned grebes,

187 goldeneyes, scoters), while others have a much more patchy distribution of occurrence

188 (loons, rhinoceros auklets, pigeon guillemots). These patterns become even more apparent when

189 we examine the sites in the upper quartile (75-100\%) of the estimated occupancy probabilities

190 across sites (Fig. 4-5). Some maps of very rare or very common species may not be informative,

191 but areas of high bird density become more apparent when our estimated occupancy probabilities

192 are calculated by group (Fig. 6). For example, each loon species in the survey is relatively rare

193 (Fig. 3), but the aggregated spatial distribution of all loons shows several patches of high and low

194 occurrence, with the highest density of occurrence in the central-south Puget Sound (Fig. 6). 
196 waterfowl species (bufflehead, common goldeneye, surf scoter) and grebes varying the most and

197 peaking in December - January (Fig. 7). Although most of the 18 species had relatively small

198 variation over the 7-month survey period, several species exhibited monotonic increases (pelagic

199 cormorant, pigeon guillemot). Of the 18 species, the probabilities of trends in occurrence being

200 positive over the 7-year survey were greater than $80 \%$ for 14 species (Fig. 8). Western grebes,

201 white-winged scoters, and brants showed relatively strong negative trends in occurrence

202 (probabilities of negative trends $>99 \%, 84 \%, 79 \%$, respectively).

203 The 18 species in our analysis represent a gradient of occurrence probabilities and trends

204 over space. Several species from each group were relatively rare in central and south Puget

205 Sound; the rarest species included two of the alcids (common murre, marbled murrelet), western

206 grebes, all three loon species, and three of the waterfowl species (brant, harlequin duck, white-

207 winged scoter; Fig. 2, 3, 8). In contrast, horned grebes and three different waterfowl species

208 (bufflehead, common goldeneye, surf scoter) were the most widely occurring (Fig. 8).

209 Discussion

210 Analyses that incorporate both spatial and temporal variation are becoming increasingly

211 common in ecology. These types of analyses are widely applicable to virtually any type of

212 observed data, from presence-absence to continuous observation measurements (Johnson et al.

213 2013; Shelton et al. 2014). Incorporating spatially structured random effects introduces a layer of

214 statistical complexity that is warranted in many cases because predicted density estimates (both in

215 space and time) are more precise (Thorson et al. 2014b).

216 Spatially-structured citizen-science datasets have been used at a large spatial scale,

217 particularly in quantifying shifts in phenology linked to climate. One of the most frequently

218 documented changes by citizen-science efforts has been shifts in breeding seasons (Hitch \&

219 Leberg 2007; Hurlbert \& Liang 2012; Mayer 2010). Spatially-structured statistical models have 
220 been fit to these types of datasets to improve estimates of trends (Hurlbert \& Liang 2012;

221 Thorson et al. 2014a), but few analyses have applied spatiotemporal models to data from citizen-

222 science efforts to identify hotspots or areas of conservation concern at a fine spatial scale.

223 Citizen-science programs, such as the Puget Sound Seabird Survey data analyzed here, offer a

224 unique opportunity because both the temporal and spatial scales of data collection are much finer

225 than national (Breeding Bird Survey) or regional (WA Department of Fish and Wildlife) efforts. If

226 volunteer-driven science can result in relative indices of occurrence or abundance, it provides an

227 extremely cost-effective approach for identifying local areas of risk (Hass et al. 2012) or potential

228 hotspots of diversity that may be useful in conservation planning (e.g., establishing reserves) or

229 permitting activities.

230 Using citizen-science data - either to complement existing datasets or to fill in data gaps

231 when other surveys are absent - is particularly important for areas or habitats at risk. The PSSS

232 may be a good model for adopting similar citizen-science efforts, either in other regions or for

233 other applications that may also be used to study food webs - examples include monitoring water

234 quality and the spread of invasive species (Silvertown 2009). In addition to the historic decline of

235 many seabird species (Bower 2009), there are a number of other human impacts that have caused

236 shifts or reorganization in the prey base (Blight et al. 2014) or competitors of seabirds (Harvey et

237 al. 2012). These impacts could include effects of overfishing or bycatch (and associated impacts

238 of derelict fishing gear; Good et al. 2009), climate change, toxins (Good et al. 2014), habitat loss

239 (Raphael et al. 2014), altered freshwater flow regimes, and the recovery of many top predators to

240 historic levels (pinnipeds, harbor porpoise, bald eagles).

241 Although many seabird species in the Puget Sound region are thought to be depleted

242 relative to abundances in the 1960s-1970s (Bower 2009; Vilchis et al. 2014), our results present a

243 more optimistic picture for a number of species over the last decade. Of the 18 species included

244 in our analysis, we found strong support for 14 having increasing probabilities of occurrence, and 
245 these results are in agreement with recent studies in the region (for example, nesting surveys

246 suggest Rhinoceros auklets are also increasing; Pearson et al. 2013). Many of the species that are

247 occurring more frequently are those that breed in the region (Table 2). In the list of indicator

248 species compiled by Pearson \& Hamel (2013), some of these species (scoters, murrelets) were

249 declining significantly when considering trends based on total abundance, so it is possible that

250 species in decline have a less aggregated spatial distribution, resulting in their probability of

251 detection increasing. Another possibility is that the PSS survey measures occurrence close to

252 land, while trends from other surveys may represent slightly different habitats. Of the species not

253 increasing, one species provided weak support for declining occurrence (white-winged scoter),

254 and three species provided strong support for continued declines in occurrence (brant, western

255 grebe, red-necked grebe). These three species in decline are also concerning because they are

256 already rarely seen species in the PSSS data (Fig. 8).

257 There is no obvious mechanism for why the three declining species in our analysis exhibit

258 a declining trend in occupancy, but some of these declines may be occurring at breeding colonies

259 (not in Puget Sound) or resulting from shifts in prey abundance in the Puget Sound region. Some

260 recent evidence suggests that there have been long-term changes in the base of the food web of

261 the Salish Sea (Blight et al. 2014), and over-wintering seabird species that rely on forage fish are

262 declining (Vilchis et al. 2014). Another mechanism that may also be related to shifts in the spatial

263 distribution of prey is the large-scale shifts in seabird species' ranges. For example, Wilson et al.

264 (2013) used citizen-science data to show that western grebes appear to have shifted out of Puget

265 Sound region to the southern end of the California Current. Our estimated declines in occupancy

266 over the last seven years are largely in agreement with a continued decline in the occurrence of

267 western grebes in the region. Like western grebes, brants and white-winged scoters over-winter in

268 Puget Sound but breed elsewhere, and thus may be affected by threats in other ecosystems.

269 Though the exact mechanisms responsible for these trends are not known, our trend estimates 
270 may be useful in prioritizing monitoring efforts or refining existing marine bird or ecosystem

271 indicators in the region (Kershner et al. 2011; Pearson \& Hamel 2013).

272 Although the focus of our volunteer-driven surveys in the Puget Sound region are focused

273 on identifying spatial hotspots and improving estimates of annual trends, citizen-science efforts

274 like the PSSS may provide additional valuable baseline monitoring. The 7 year dataset analyzed

275 here provides both a baseline for seabird monitoring in 2014, and also allows us to do a

276 retrospective analysis of trends over this time period. For example, in the event of an oil spill in

277 the region, PSSS data could provide 7+ years of pre-spill information on seabird distribution and

278 abundance for comparison. Having a 7-year period as a baseline instead of just a single year is

279 useful in that the year-to-year variability can be quantified. Such citizen-science efforts may also

280 be scalable to different types of data collection that also involve spatially structured threats to

281 marine ecosystems such as harmful algal blooms, ocean acidification, and fisheries activities.

\section{Acknowledgments:}

283 The Puget Sound Seabird Survey was conceived, developed and implemented by the

284 Seattle Audubon Society and continues to be a major focus of their science efforts. We thank the

$285250+$ observers who braved wind and rain to collect bird data; this work would not be possible

286 without their dedication. Thanks to J. Smith, C. Jordan, T. Good, and two anonymous reviewers

287 for providing helpful reviews of earlier drafts of this manuscript. 
288 Literature Cited

289 Anderson EM, Bowe JL, Nysewander DR, Evenson JR, and Lovvorn JR. 2009. Changes in

290 avifaunal abundance in a heavily-used wintering and migration site in Puget Sound,

291 Washington during 1966-2007. Marine Ornithology 37:19-27.

292 Banerjee S, Gelfand AE, and Carlin BP. 2005. Hierarchical Modeling and Analysis for Spatial

293 Data: Chapman \& Hall/CRC.

294 Blight LK, Hobson KA, Kyser TK, and Arcese P. 2014. Changing gull diet in a changing world:

295 A 150 -year stable isotope $(\delta 13 \mathrm{C}, \delta 15 \mathrm{~N})$ record from feathers collected in the Pacific

296 Northwest of North America. Global Change Biology, In press.

297 Bower JL. 2009. Changes in marine bird abundance in the Salish Sea. Marine Ornithology 37:9-

$298 \quad 17$.

299 Cabeza M, and Moilanen A. 2001. Design of reserve networks and the persistence of biodiversity.

$300 \quad$ Trends in Ecology \& Evolution 16:242-248.

301 Cooper CB, Dickinson J, Phillips T, and Bonney R. 2007. Citizen science as a tool for

302 conservation in residential ecosystems. Ecology and Society 12.

303 Cressie N, and Wikle CK. 2011. Statistics for Spatio-Temporal Data. Hoboken, NJ: Wiley.

304 Crewe T, Barry K, Davidson P, and Lepage D. 2012. Coastal waterbird population trends in the

305 Strait of Georgia 1999-2011: results from the first 12 years of the British Columbia

306 Coastal Waterbird Survey. . Brittish Columbia Birds 22:8-35.

307 Evenson JR. 2010. Analysis of marine bird data, Puget Sound Assessment and Monitoring

308 Program. Olympia, WA: Washington Department of Fish and Wildlife.

309 Gaydos JK, and Pearson SF. 2011. Birds and mammals that depend on the Salish Sea: A

$310 \quad$ compilation. Northwest Naturalist 92:79-94.

311 Gelman A, and Rubin DB. 1992. Inference from iterative simulation using multiple sequences.

$312 \quad$ Statistical Science 7:457-511. 
313 Good TP, June JA, Etnier MA, and Broadhurst MK. 2009. Ghosts of the Salish Sea: threats to

314 marine birds in Puget Sound and the Northwest straits from derelict fishing gear. Marine

$315 \quad$ Ornithology 37:67-76.

316 Good TP, Pearson SF, Hodum P, Boyd D, Anulacio BF, and Ylitalo GM. 2014. Persistent organic

317 pollutants in the diet of rhinoceros auklets (Cerorhinca monocerata) breeding in Puget

318 Sound and the northern California Current. Marine Pollution Bulletin: 86:367-378.

319 Gotelli NJ. 2000. Null model analysis of species co-occurrence patterns. Ecology 81:2606-2621.

320 Gotelli NJ, and McGill BJ. 2006. Null versus neutral models: what's the difference. Ecography

$321 \quad 29: 793-800$.

322 Hamel NJ, Burger AE, Charleton K, Davidson P, Lee S, Bertram DF, and Parrish JK. 2009.

323 Bycatch and beached birds: assessing mortality impacts in coastal net fisheries using

324 marine bird strandings. Marine Ornithology 37:41-60.

325 Hass T, Hyman J, and Semmens BX. 2012. Climate change, heightened hurricane activity, and

326 extinction risk for an endangered tropical seabird, the black-capped petrel Pterodroma

327 hasitata. Marine Ecology Progress Series 454:251-261.

328 Harvey CJ, Williams GD, and Levin PS. 2012. Food web structure and trophic control in central

329 Puget Sound. Estuaries and Coasts 35:821-838.

330 Hitch AT, and Leberg PL. 2007. Breeding distributions of north American bird species moving

331 north as a result of climate change. Conservation Biology 21:534-539.

332 Holmes EE. 2001. Estimating risks in declining populations with poor data. Proceedings of the

$333 \quad$ National Academy of Sciences of the United States of America 98:5072-5077.

334 Hooten MB, and Wikle CK. 2008. A hierarchical Bayesian non-linear spatio-temporal model for

335 the spread of invasive species with application to the Eurasian Collared-Dove.

336 Environmental and Ecological Statistics 15:59-70. 
337 Hurlbert AH, and Liang ZF. 2012. Spatiotemporal variation in avian migration phenology: citizen 338 science reveals effects of climate change. PLOS ONE 7.

339 Jetz W, Wilcove DS, and Dobson AP. 2007. Projected impacts of climate and land-use change on 340 the global diversity of birds. Plos Biology 5:1211-1219.

341 Johnson DS, Conn PB, Hooten MB, Ray JC, and Pond BA. 2013. Spatial occupancy models for $342 \quad$ large data sets. Ecology 94:801-808.

343 Kershner J, Samhouri JF, James CA, and Levin PS. 2011. Selecting indicator portfolios for 344 marine species and food webs: a Puget Sound case study. PLoS ONE 6.

345 Latimer AM, Wu SS, Gelfand AE, and Silander JA. 2006. Building statistical models to analyze $346 \quad$ species distributions. Ecological Applications 16:33-50.

347 Litle K, Parrish JK, and Dolliver J. 2007. The Coastal Observation and Seabird Survey Team348 Citizens Monitoring Coastal Environmental Health in Alaska. In: Brewer R, editor. 349 Community-Based Coastal Observing in Alaska: Aleutian Life Forum 2006. Fairbanks: $350 \quad$ Alaska Sea Grant College Program, AK-SG-07-03. . p 21-38.

351 MacKenzie DI, Nichols JD, Royle JA, Pollock KH, Bailey LL, and Hines JE. 2006. Occupancy 352 estimation and modeling: inferring patterns and dynamics of species occurrence.

353 Burlington, MA: Elsevier.

354 Mayer A. 2010. Phenology and Citizen Science. BioScience 60:172-175.

355 Naujokaitis-Lewis IR, Curtis JMR, Arcese P, and Rosenfeld J. 2009. Sensitivity analyses of 356 spatial population viability analysis models for species at risk and habitat conservation 357 planning. Conservation Biology 23:225-229.

358 Nysewander DR, Evenson JR, Murphie BL, and Cyra TA. 2005. Report of marine bird and 359 marine mammal component, Puget Sound ambient monitoring program, for July 1992 to 360 December1999. Washington State Department of Fish and Wildlife, Olympia, WA.

361 Parrish JK, Bond N, Nevins H, Mantua N, Loeffel R, Peterson WT, and Harvey JT. 2007. 
362 Beached birds and physical forcing in the California Current System. Marine Ecology$363 \quad$ Progress Series 352:275-288.

364 Pearson SF, and Hamel NJ. 2013. Marine and terrestrial bird indicators for Puget Sound.

365 Washington Department of Fish and Wildlife and Puget Sound Partnership, Olympia, WA, $36655 \mathrm{pp}$.

367 Pearson SF, Hodum PJ, Good TP, Schrimpf M, and Knapp SM. 2013. A model approach for 368 estimating colony size, trends, and habitat associations of burrow-nesting seabirds. $369 \quad$ Condor 115:356-365.

370 Plummer M. 2003. JAGS: A program for analysis of Bayesian graphical models using Gibbs

371 Sampling. Proceedings of the 3rd International Workshop on Distributed Statistical

372 Computing. Vienna, Austria.

373 Puget Sound Partnership. 2009. Puget Sound Action Agenda, Protecting and Restoring the Puget 374 Sound Ecosystem by 2020. . Olympia, Washington. 204 pages. http://www.psp.wa.gov.

375 Puget Sound Partnership. 2013. State of the Sound: A Biennial Report on the Recovery of Puget 376 Sound. Tacoma, Washington. Page 177.

377 Puget Sound Partnership. 2014. The 2014/2015 Action Agenda for Puget Sound. Available from $378 \quad$ http://www.psp.wa.gov/.

379 R Core Team. 2014. R: A language and environment for statistical computing. R Foundation for 380 Statistical Computing, Vienna, Austria. URL http://www.R-project.org/.

381 Raphael MG, Shirk AJ, Falxa GA, and Pearson SF. 2014. Habitat associations of marbled 382 murrelets during the nesting season in nearshore waters along the Washington to 383 California coast. Journal of Marine Systems In press.

384 Royle JA, and Kery M. 2007. A Bayesian state-space formulation of dynamic occupancy models. $385 \quad$ Ecology 88:1813-1823. 
386 Ruckelshaus MH, and McClure MM. 2007. Sound Science: Synthesizing ecological and

387

388

389

390

391

392

393

394

395

396

397

398

399

400

401

402

403

404

405

406

407

408

409

410

socioeconomic information about the Puget Sound ecosystem. Prepared in cooperation with the Sound Science collaborative team. U.S. Dept. of Commerce, National Oceanic \& Atmospheric Administration, Northwest Fisheries Science Center. Seattle, Washington. 93 pp. At:

http://www.nwfsc.noaa.gov/research/shared/sound_science/documents/SoundScience07.p df.

Sauer JR, Hines JE, Fallon JE, Pardieck KL, Ziolkowski DJJ, and Link WA. 2014. The North American Breeding Bird Survey, Results and Analysis 1966 - 2012. Version 02.19.2014 USGS Patuxent Wildlife Research Center, Laurel, MD.

Shelton AO, Thorson JT, Ward EJ, and Feist BE. 2014. Spatial, semi-parametric models improve estimates of species abundance and distribution. Canadian Journal of Fisheries and Aquatic Sciences In press.

Silvertown J. 2009. A new dawn for citizen science. Trends in Ecology \& Evolution 24:467-471.

Su Y-S, and Yajima M. 2014. R2jags: A Package for Running jags from R. R package version 0.04-01. http://CRAN.R-project.org/package=R2jags.

Tallis H, and Polasky S. 2009. Mapping and valuing ecosystem services as an approach for conservation and natural-resource management. Annals of the New York Academy of Sciences 1162:265-283.

Thorson JT, Scheuerell MD, Semmens BX, and Semmens CP. 2014a. Demographic modeling of citizen science data informs habitat preferences and population dynamics of recovering fishes. Ecological Applications In press.

Thorson JT, Skaug H, Kristensen K, Shelton AO, Harms J, and Benante J. 2014b. The importance of spatial models for estimating the type and strength of density dependence. Ecological Applications In revision. 
411 Vilchis IL, Johnson CK, Evenson JR, Pearson SF, Barry KL, Davidson P, Raphael MG, and

412 Gaydos JK. 2014. Assessing ecological correlates of marine bird declines to inform

413 marine conservation. Conservation Biology In press.

414 Ward EJ, Chirakkal H, Gonzalez-Suarez M, Aurioles-Gamboa D, Holmes EE, and Gerber L.

415 2010. Inferring spatial structure from time-series data: using multivariate state-space

416 models to detect metapopulation structure of California sea lions in the Gulf of California,

417 Mexico. Journal of Applied Ecology 47:47-56.

418 Ward EJ, Pess GR, Anlauf-Dunn K, and Jordan CE. 2012. Applying time series models with

419 spatial correlation to identify the scale of variation in habitat metrics related to threatened

420 coho salmon (Oncorhynchus kisutch) in the Pacific Northwest. Canadian Journal of

$421 \quad$ Fisheries and Aquatic Sciences 69:1773-1782.

422 Wilson S, Anderson EM, A.S.G. W, Bertram DF, and Arcese P. 2013. Citizen science reveals an

423 extensive shift in the winter distribution of migratory western grebes. PLoS ONE

424 8:e65408. doi:65410.61371/journal.pone.0065408. 


\section{Table $\mathbf{1}$ (on next page)}

Table 1

Name, latitude, and longitude of the 62 sites included in our analysis 
Table 1. Name, latitude, and longitude of the 62 sites included in our analysis

\begin{tabular}{|c|c|c|c|c|c|}
\hline$\underline{\text { Site }}$ & $\frac{\text { Lat }}{\left({ }^{\circ} \underline{N}\right)}$ & $\frac{\text { Lon }}{\left({ }^{\circ} \underline{W}\right)}$ & $\underline{\text { Site }}$ & $\frac{\text { Lat }}{\left({ }^{\circ} \underline{N}\right)}$ & $\frac{\text { Lon }}{\left({ }^{\circ} \underline{W}\right)}$ \\
\hline 1. 60th St Viewpoint & 47.6723 & 122.4062 & 32. Mee Kwa Mooks & 47.5637 & 122.4070 \\
\hline 2. Alki Beach & 47.5784 & 122.4144 & 33. Mukilteo State Park & 47.9478 & 122.3071 \\
\hline 3. Boston Harbor & 47.1396 & 122.9029 & 34. Myrtle Edwards Park & 47.6268 & 122.3775 \\
\hline 4. Brace Point & 47.5152 & 122.3964 & 35. Narrows Park & 47.2671 & 122.5641 \\
\hline 5. Brown's Point & 47.3058 & 122.4443 & 36. Normandy Beach Park & 47.4116 & 122.3401 \\
\hline 6. Burfoot County Park & 47.1310 & 122.9046 & 37. North Redondo Boardwalk & 47.3507 & 122.3238 \\
\hline 7. Carkeek Park & 47.7125 & 122.3796 & 38. Olympia waterfront & 47.0582 & 122.9020 \\
\hline 8. Cromwell East & 47.2709 & 122.6110 & 39, Owens Beach Pt Defiance & 47.3128 & 122.5280 \\
\hline 9. Cromwell West & 47.2714 & 122.6191 & 40. Penn Cove Pier & 48.2228 & 122.6883 \\
\hline 10. Dash Pt State Park & 47.3204 & 122.4141 & 41. Penrose State Park & 47.2601 & 122.7450 \\
\hline 11. DeMolay Boys Camp (E) & 47.2777 & 122.6662 & 42. Pier 57 & 47.6062 & 122.3429 \\
\hline 12. DeMolay Boys Camp (W) & 47.2775 & 122.6668 & 43. Pier 70 & 47.6149 & 122.3573 \\
\hline 13. Discovery Park West & 47.6674 & 122.4227 & 44. Point No Point & 47.9122 & 122.5265 \\
\hline 14. Dumas Bay Park & 47.3263 & 122.3853 & 45. Pt Wilson & 48.1441 & 122.7538 \\
\hline 15. Duwamish Head & 47.5954 & 122.3876 & 46. Purdy Spit South & 47.3817 & 122.6348 \\
\hline 16. Edmonds north & 47.8114 & 122.3891 & 47. Raft Island north & 47.3318 & 122.6700 \\
\hline 17. Edmonds south & 47.8033 & 122.3947 & 48. Raft Island south & 47.3261 & 122.6675 \\
\hline 18. Elliott Bay Water Taxi Pier & 47.5898 & 122.3800 & 49. Richmond Beach & 47.7636 & 122.3858 \\
\hline 19. Fox Island Fishing Pier & 47.2287 & 122.5898 & 50. Ruston Way & 47.2948 & 122.4990 \\
\hline 20. Frye Cove County Park & 47.1152 & 122.9643 & 51. Saltwater State Park & 47.3728 & 122.3249 \\
\hline 21. Golden Gardens & 47.6928 & 122.4056 & 52. Seahurst Park & 47.4781 & 122.3638 \\
\hline 22. Howarth State Park & 47.9642 & 122.2407 & 53. Sinclair Inlet & 47.5398 & 122.6621 \\
\hline 23. Jack Hyde Park & 47.2758 & 122.4622 & 54. South Redondo Boardwalk & 47.3434 & 122.3328 \\
\hline 24. Kayak Point State Park & 48.1373 & 122.3668 & 55. The Cove & 47.4428 & 122.3563 \\
\hline 25. Kopachuck & 47.3101 & 122.6874 & 56. Thea's Park & 47.2620 & 122.4398 \\
\hline 26. Les Davis Pier & 47.2836 & 122.4813 & 57. Three Tree Point & 47.4522 & 122.3792 \\
\hline 27. Libbey Beach County Park & 48.2322 & 122.7668 & 58. Titlow Beach & 47.2469 & 122.5536 \\
\hline 28. Lincoln Park & 47.5263 & 122.3949 & 59. Tolmie State Park & 47.1209 & 122.7761 \\
\hline 29. Lowman Park & 47.5403 & 122.3974 & 60. Totten Inlet & 47.1540 & 122.9645 \\
\hline 30. Luhr Beach & 47.1008 & 122.7272 & 61. West Point north & 47.6624 & 122.4335 \\
\hline 31. Magnolia Bluff & 47.6313 & 122.3954 & 62. West Point south & 47.6610 & 122.4330 \\
\hline
\end{tabular}




\section{Table 2 (on next page)}

Table 2

The 18 species included in our analysis of the Puget Sound Seabird Survey. Rows in bold represent species that breed locally (in Puget Sound). 
Table 2. The 18 species included in our analysis of the Puget Sound Seabird Survey.

Rows in bold represent species that breed locally (in Puget Sound).

\begin{tabular}{ccc} 
Common name & Scientific name & Group \\
\hline Common murre & Uria aalge & Alcids \\
Marbled murrelet & Brachyramphus marmoratus & Alcids \\
Pigeon guillemot & Cepphus columba & Alcids \\
Rhinoceros auklet & Cerorhinca monocerata & Alcids \\
Brandt's cormorant & Phalacrocorax penicillatus & Cormorants \\
Pelagic cormorant & Phalacrocorax pelagicus & Cormorants \\
Horned grebe & Podiceps auritus & Grebes \\
Red-necked grebe & Podiceps grisegena & Grebes \\
Western grebe & Aechmophorus occidentalis & Grebes \\
Common loon & Gavia immer & Loons \\
Pacific loon & Gavia pacifica & Loons \\
Red-throated loon & Gavia stellata & Loons \\
Brant & Branta bernicla & Waterfowl \\
Bufflehead & Bucephala albeola & Waterfowl \\
Common goldeneye & Bucephala clangula & Waterfowl \\
Harlequin duck & Histrionicus histrionicus & Waterfowl \\
Surf scoter & Melanitta perspicillata & Waterfowl \\
White-winged scoter & Melanitta deglandi & Waterfowl
\end{tabular}


1

Figure 1.

Minutes of sampling effort recorded (across all observer pairs and months in the Puget Sound Seabird Survey that are included in our analysis), 2007-2014.

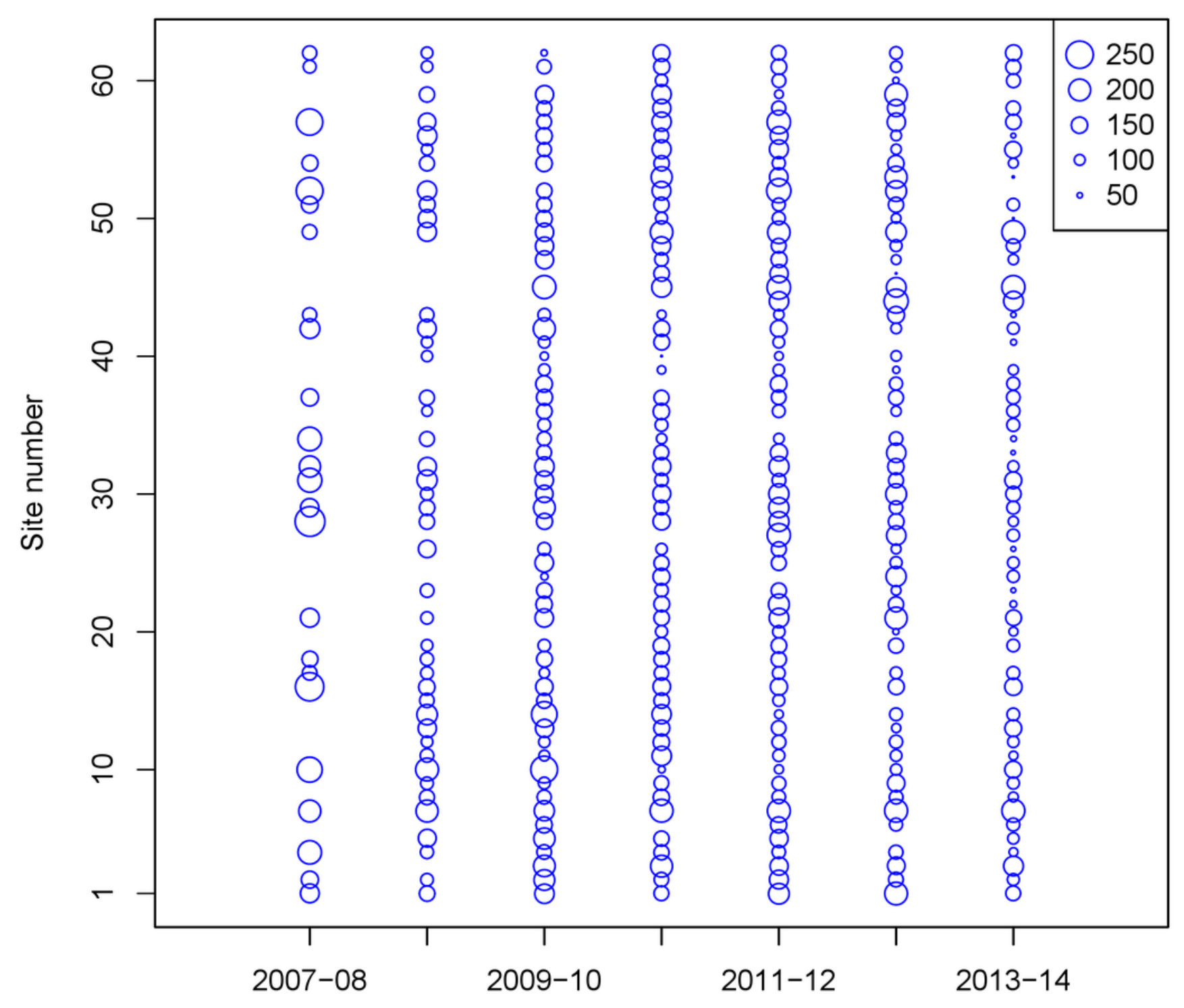


2

Figure 2.

Estimated probability of occurrence for the 62 sites included in our analysis. Presented estimates are for alcids, cormorants, and grebes in December 2013. The color scale used to represent occurrence probabilities ranges from 0 (a species is not present) to 1 (occurrence is $100 \%$ ). 


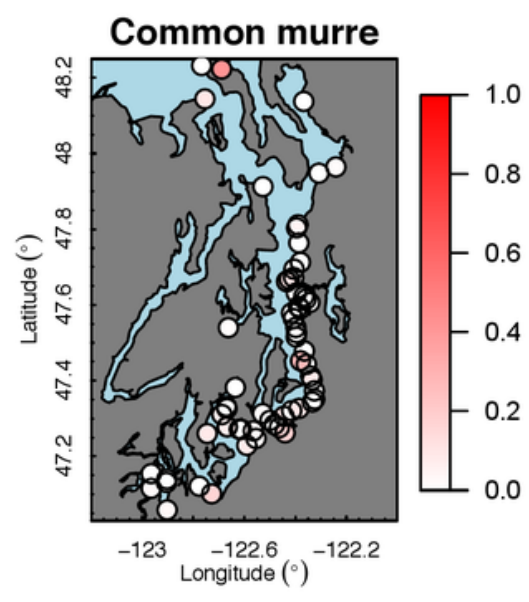

Rhinoceros auklet
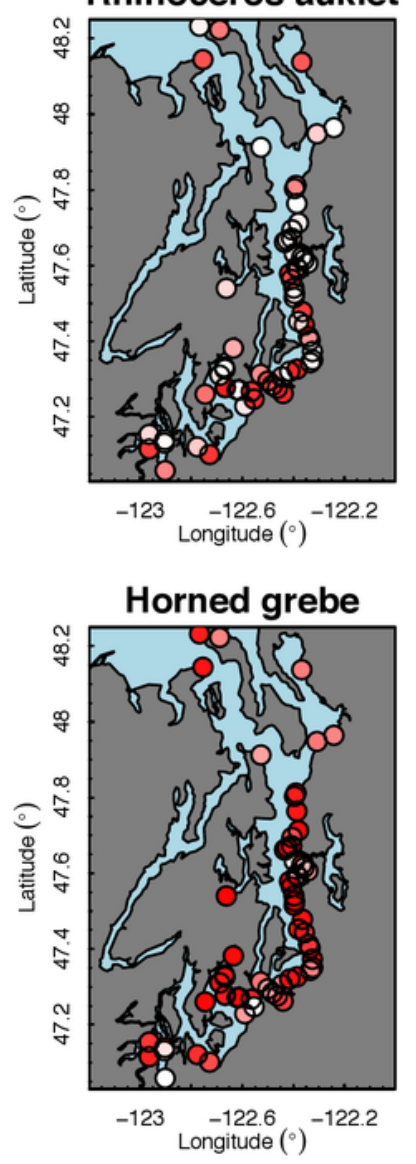

Marbled murrelet

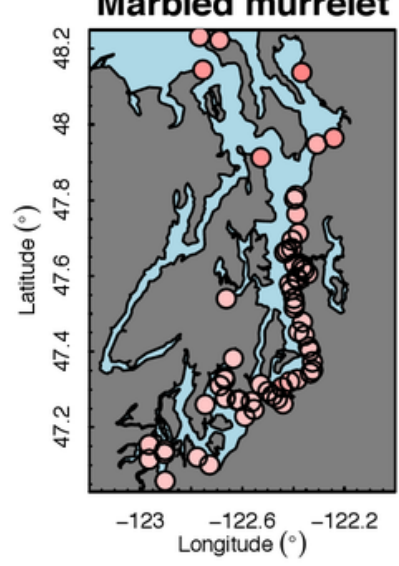

Brandt's cormorant

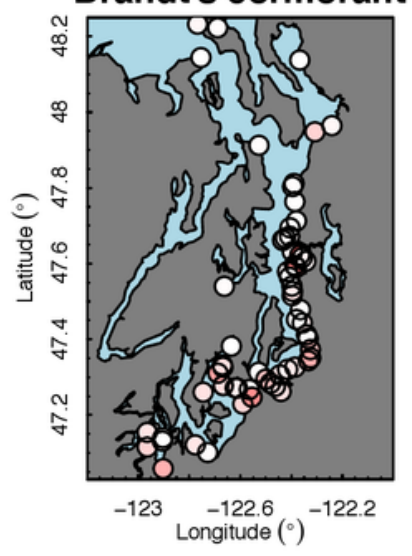

Red-necked grebe

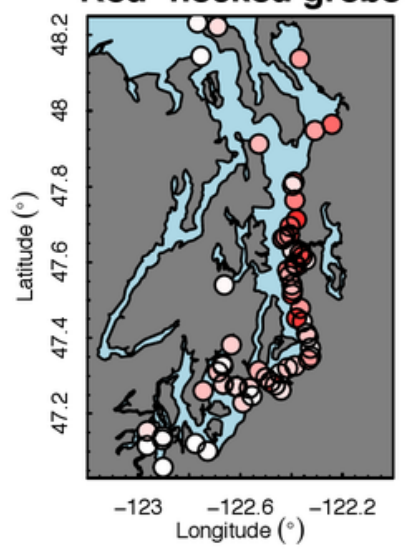

Pigeon guillemot

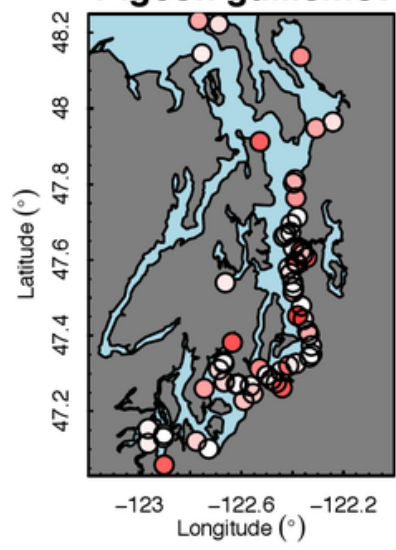

Pelagic cormorant
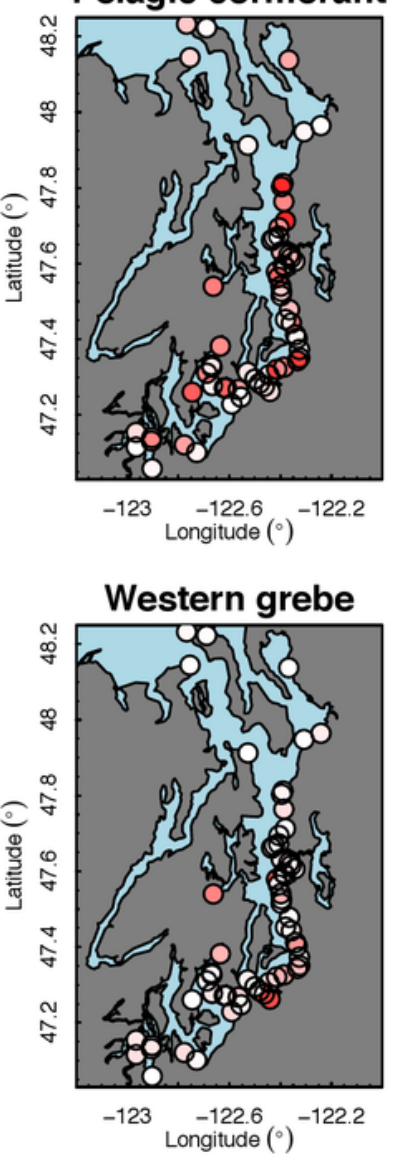


\section{3}

Figure 3.

Estimated probability of occurrence for the 62 sites included in our analysis. Presented estimates are for loons and waterfowl in December 2013. The color scale used to represent occurrence probabilities ranges from 0 (a species is not present) to 1 (occurrence is $100 \%$ ).
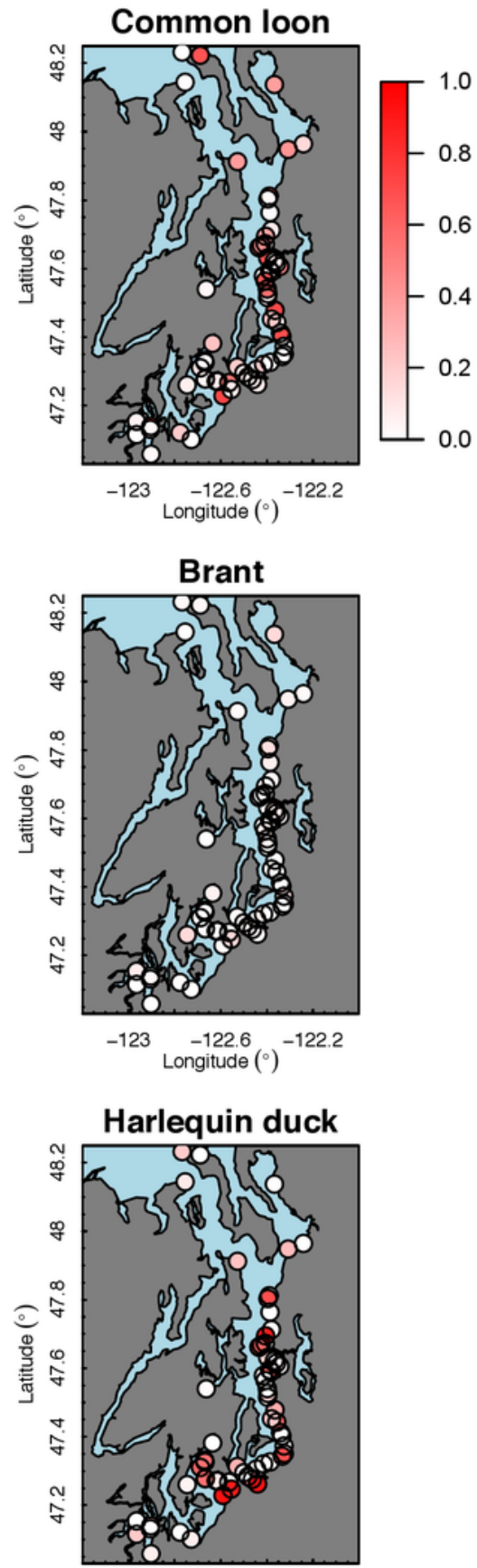

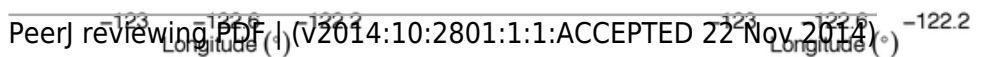
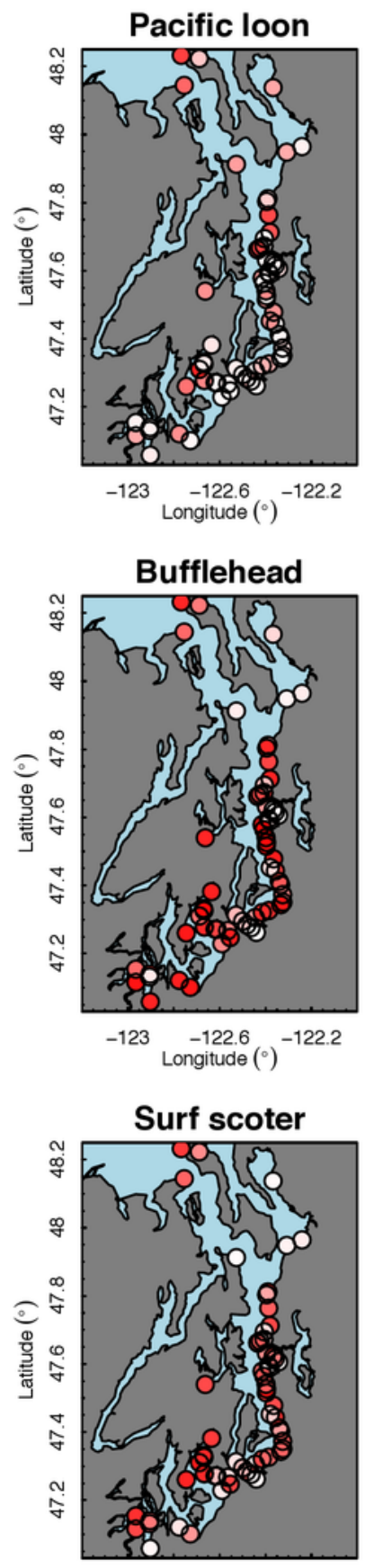
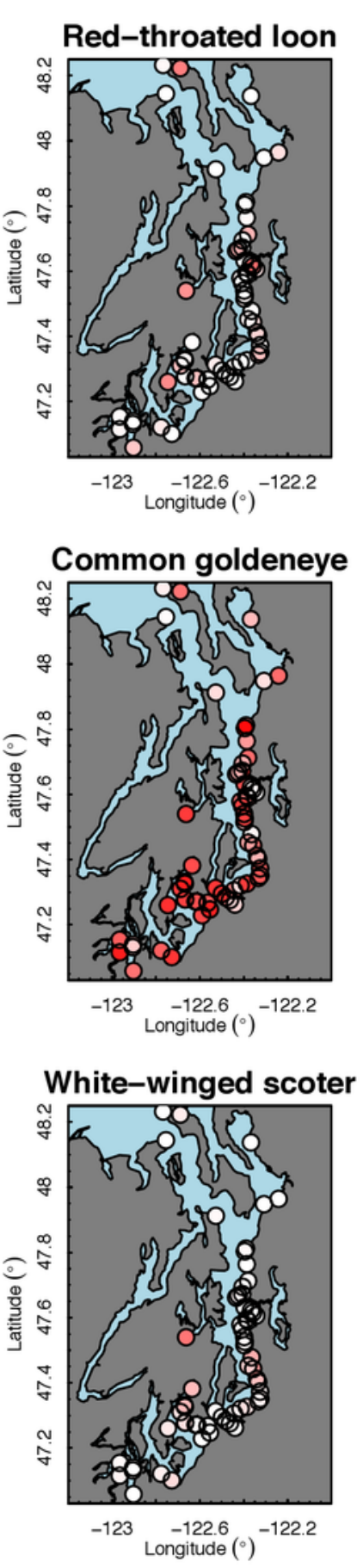


\section{4}

Figure 4.

Estimated hotspots of occurrence for the 62 sites included in our analysis, defined as probabilities in the upper quartile (75-100\%) across sites (Fig. 2). Presented estimates are for alcids, cormorants, and grebes in December 2013. The color scale used to represent sites in the upper quartile is red $(>75 \%)$ or white $(<75 \%)$. 


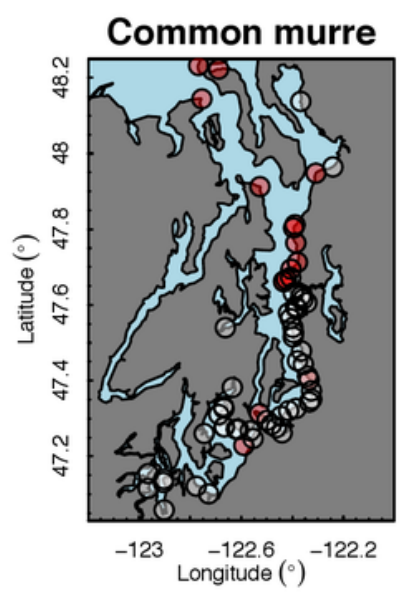

Rhinoceros auklet
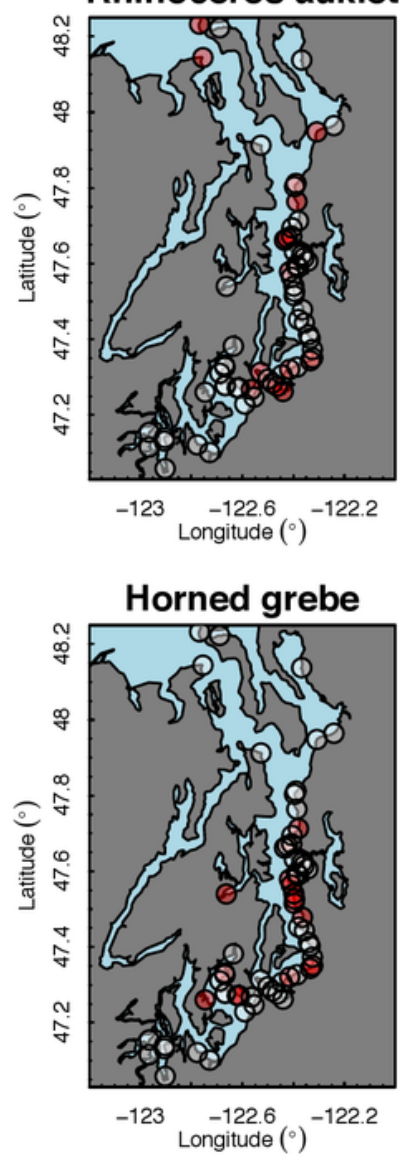

Marbled murrelet

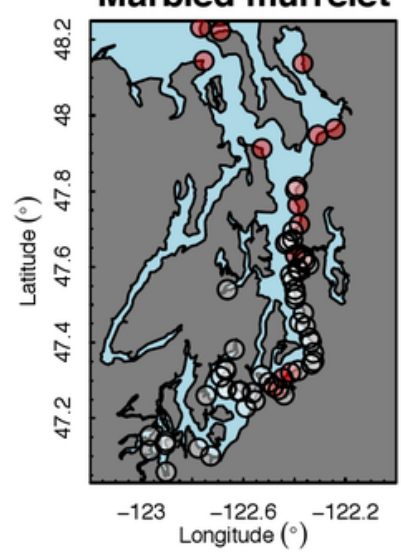

Brandt's cormorant

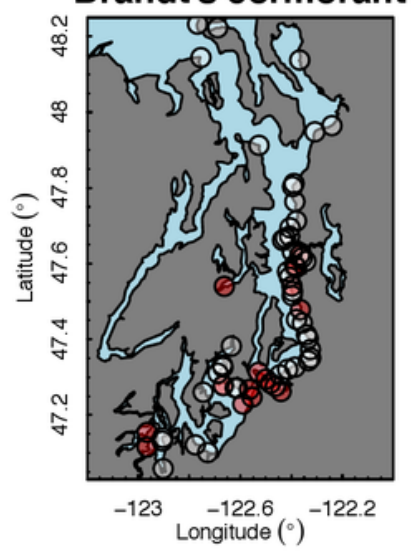

Red-necked grebe

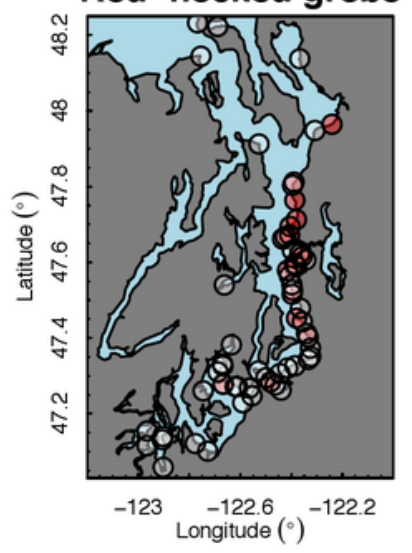

Pigeon guillemot

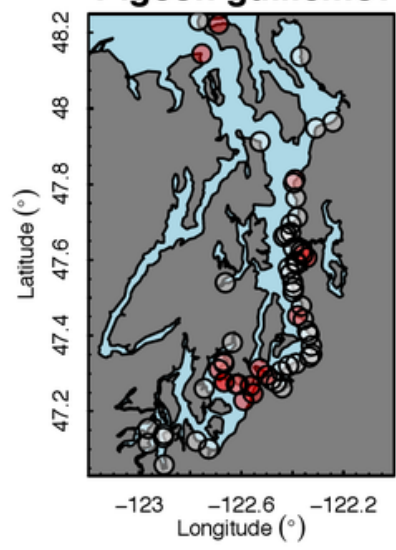

Pelagic cormorant
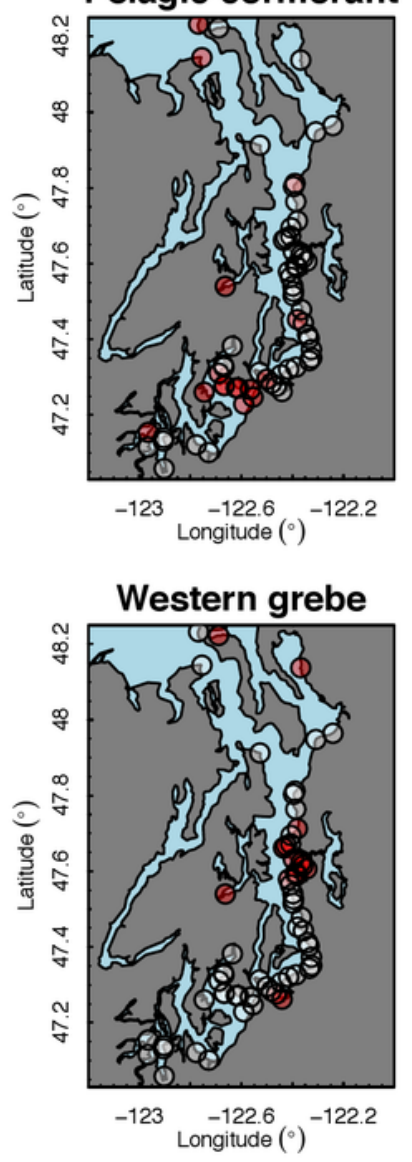


\section{5}

Figure 5.

Estimated hotspots of occurrence for the 62 sites included in our analysis, defined as probabilities in the upper quartile (75-100\%) across sites (Fig. 2). Presented estimates are for loons and waterfowl in December 2013. The color scale used to represent sites in the upper quartile is red $(>75 \%)$ or white $(<75 \%)$. 

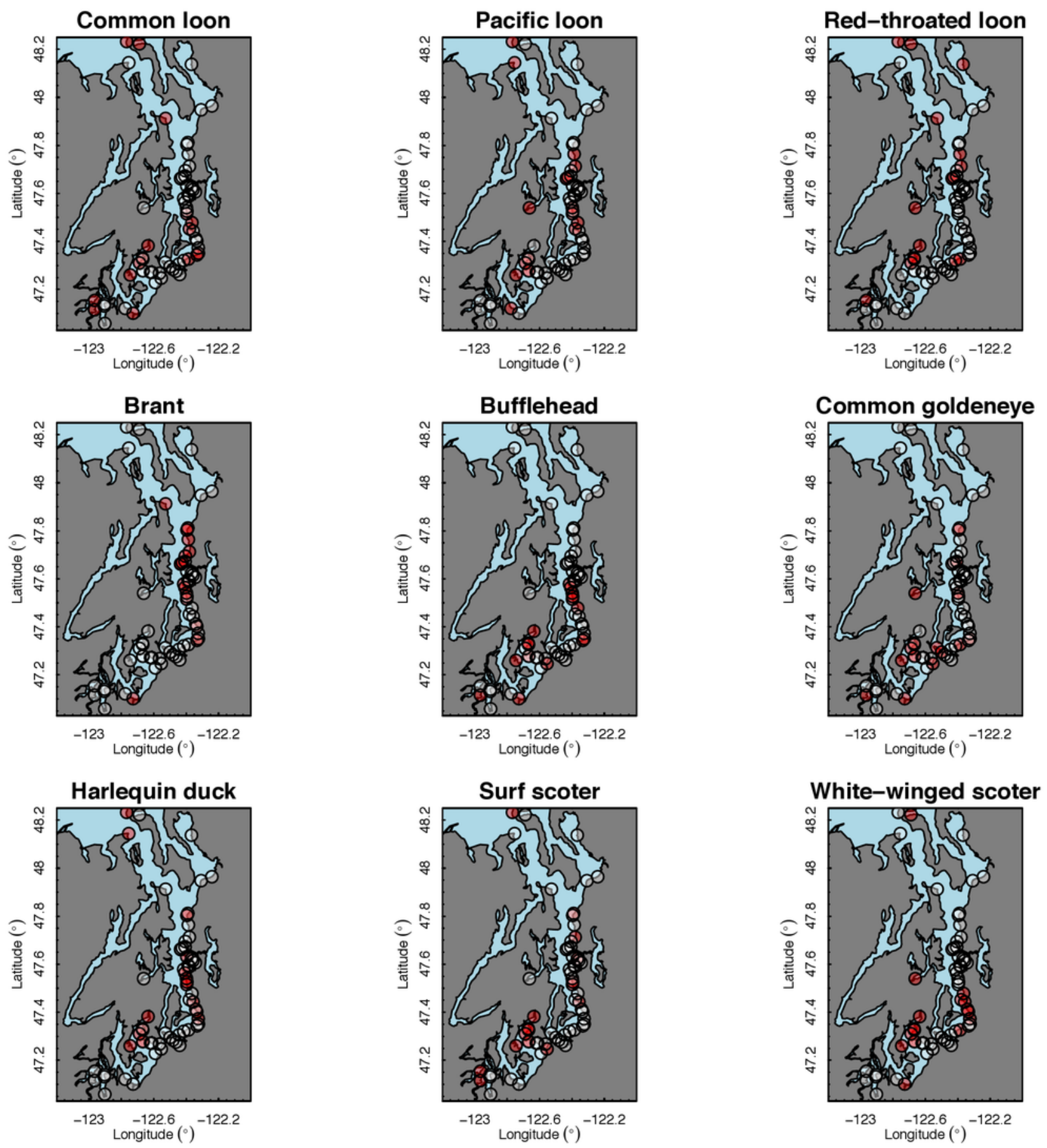
6

Figure 6.

Aggregated probabilities of occurrence for each of the five groups in our analysis, as well as for all 18 species. For groups, these represent the probability of seeing any bird that is a member of that group; for all species, these represent the probability of seeing at least 1 bird (of the 18 species in our analysis). Estimates are shown for December 2013. The color scale used to represent occurrence probabilities ranges from 0 (not present) to 1 (occurrence is $100 \%)$. 

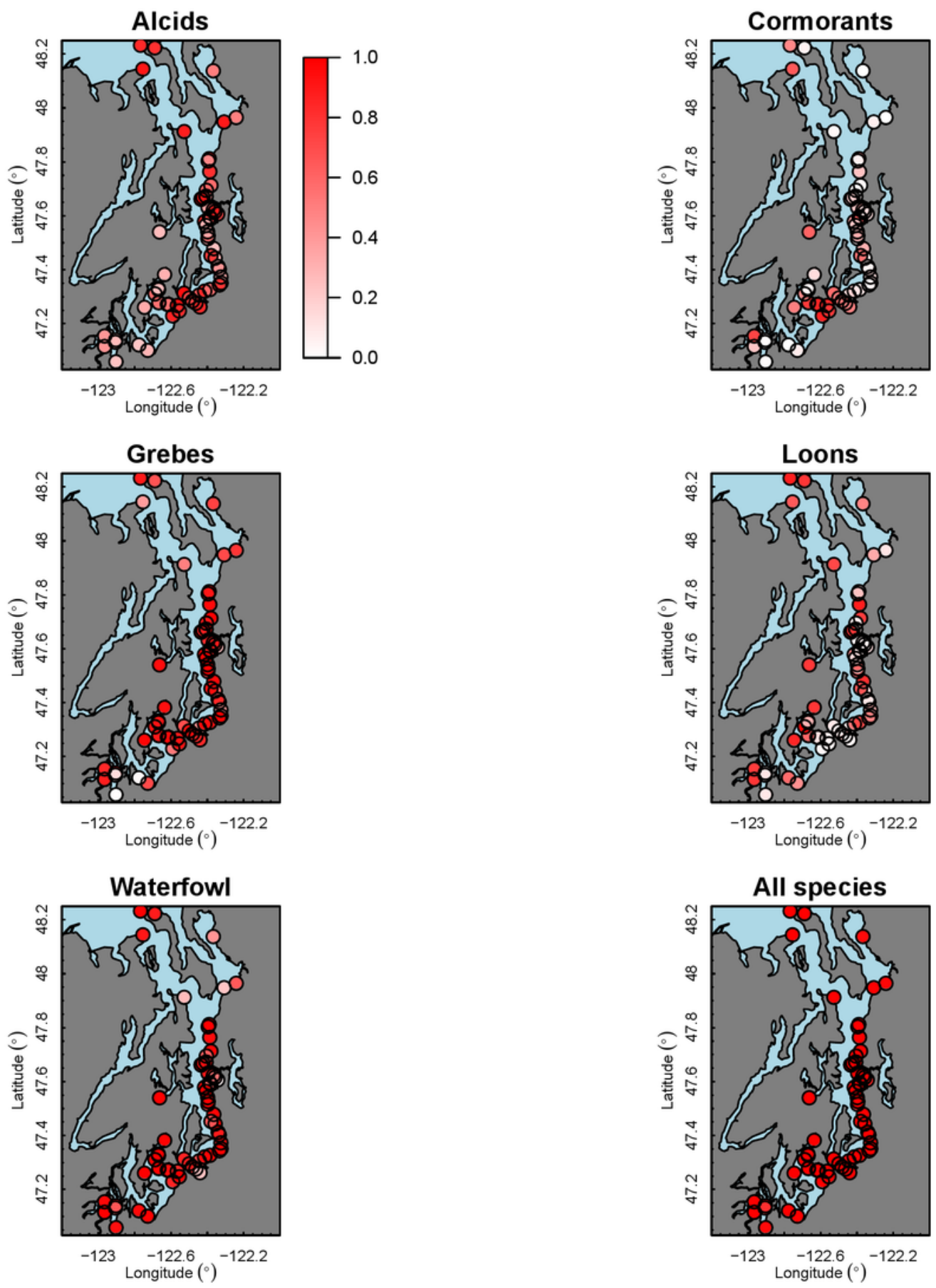


\section{7}

Figure 7.

Estimated median probabilities of occurrence by month. Estimates are shown for the most recent year (October 2013- April 2014). Estimates for November, January, and March are not shown.

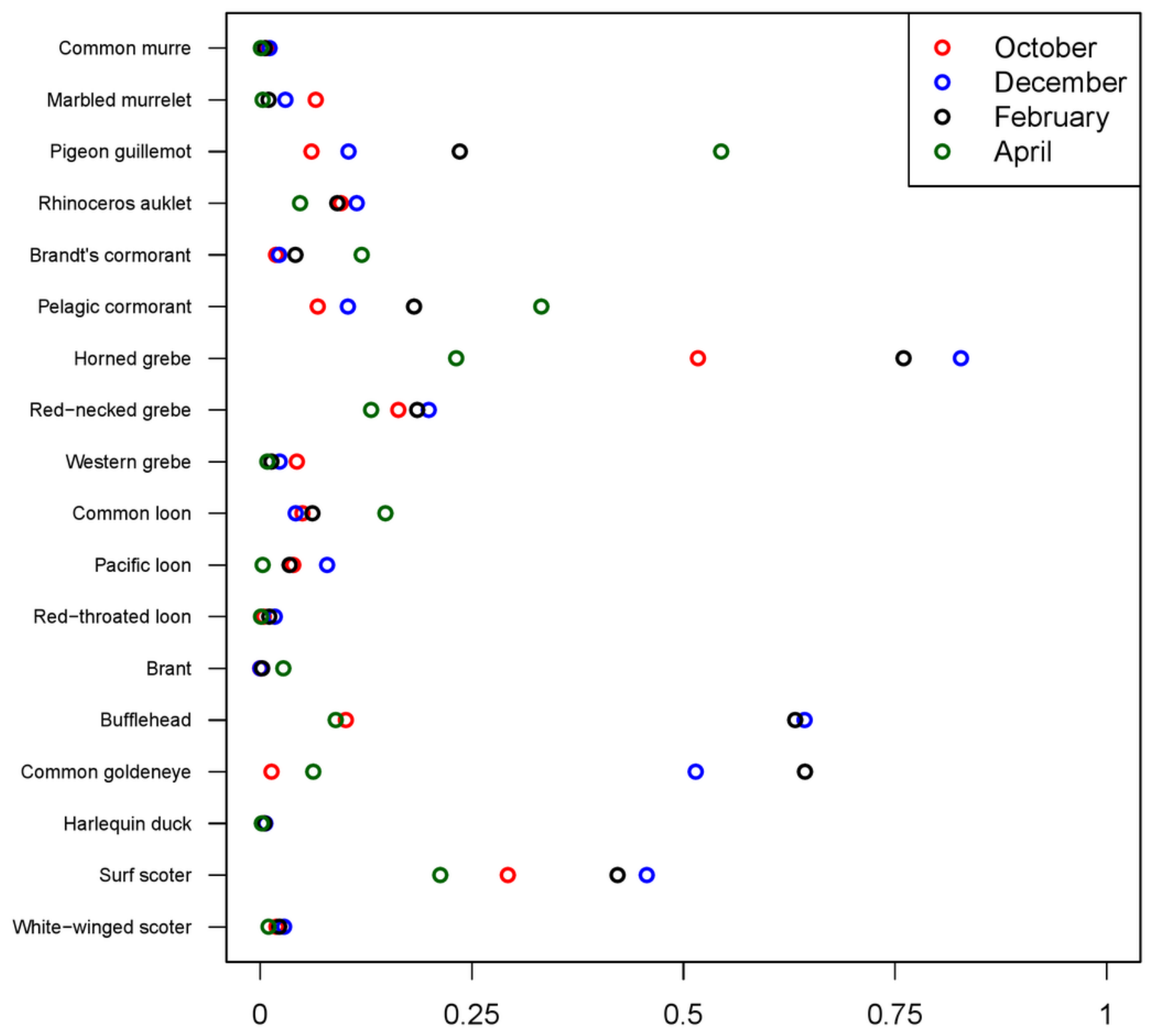


8

Figure 8.

Estimated probability of occurrence in the 2013-2014 seabird survey (with 25\%, 50\%, 75\% intervals), percent change in the probability of occurrence from 2007-2013 (25\%, 50\%, 75\% intervals), and the probability of the annual rate of change from 2007-2013 has been positive. All data (2007-2013) are used to estimate intra- and inter-annual trends. 


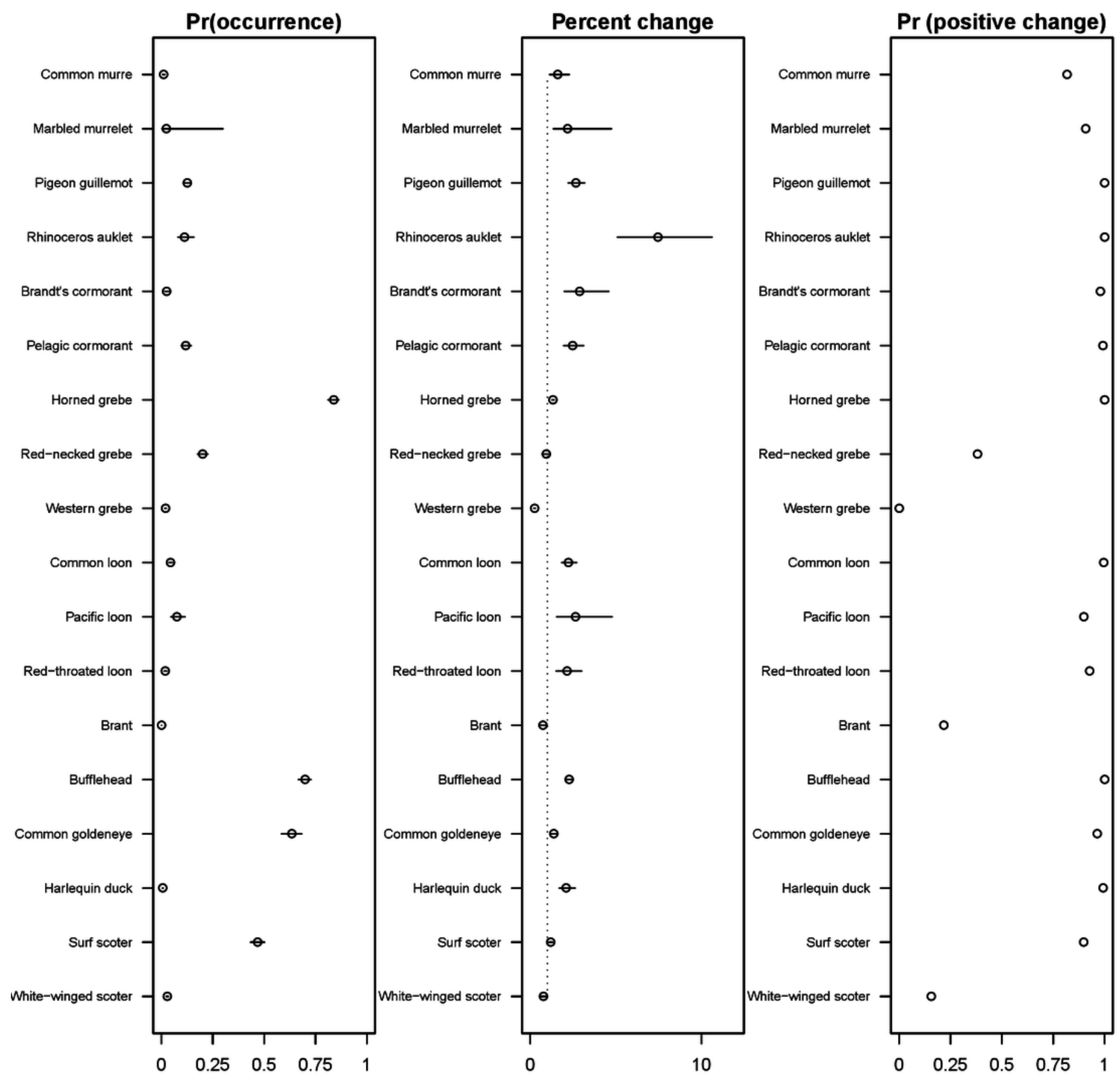

